\title{
Detection and differentiation of Entamoeba histolytica and Entamoeba dispar in clinical samples through PCR-denaturing gradient gel electrophoresis
}

\author{
P. López-López ${ }^{1}$, M.C. Martínez-López² ${ }^{2}$ X.M. Boldo-León² ${ }^{2}$ Y. Hernández-Díaz ${ }^{3}$, \\ T.B. González-Castro ${ }^{3}$, C.A. Tovilla-Zárate ${ }^{4}$ and J.P. Luna-Arias ${ }^{5}$ \\ ${ }^{1}$ Family Medicine Unit 43, Social Security Mexican Institute, Cardenas, Tabasco, Mexico \\ ${ }^{2}$ Health Sciences Academic Division, Juarez Autonomous University of Tabasco, Villahermosa, Tabasco, Mexico \\ ${ }^{3}$ Multidisciplinary Academic Division at Jalpa de Mendez, Juarez Autonomous University of Tabasco, \\ Jalpa de Mendez, Tabasco, Mexico \\ ${ }^{4}$ Multidisciplinary Academic Division at Comalcalco, Juarez Autonomous University of Tabasco, Comalcalco, Tabasco, Mexico \\ ${ }^{5}$ Center for Research and Advanced Studies, National Polytechnic Institute, Mexico City, Mexico
}

\begin{abstract}
Amebiasis is one of the twenty major causes of disease in Mexico; however, the diagnosis is difficult due to limitations of conventional microscopy-based techniques. In this study, we analyzed stool samples using polymerase chain reactiondenaturing gradient gel electrophoresis (PCR-DGGE) to differentiate between Entamoeba histolytica (pathogenic) and E. dispar (non-pathogenic). The target for the PCR amplification was a small region (228 bp) of the adh112 gene selected to increase the sensitivity of the test. The study involved 62 stool samples that were collected from individuals with complaints of gastrointestinal discomfort. Of the 62 samples, 10 (16.1\%) were positive for E. histolytica while 52 (83.9\%) were negative. No sample was positive for $E$. dispar. These results were validated by nested PCR-RFLP (restriction fragment length polymorphism) and suggest that PCR-DGGE is a promising tool to differentiate among Entamoeba infections, contributing to determine the specific treatment for patients infected with E. histolytica, and therefore, avoiding unnecessary treatment of patients infected with the non-pathogenic $E$. dispar.
\end{abstract}

Key words: Amebiasis; Neglected diseases; Diagnostic; PCR; DGGE; adh112 gene

\section{Introduction}

One of the major health problems in developing countries is amebiasis. In 1997, the World Health Organization declared this disease as the third leading cause of death due to parasitic infections $(1,2)$. Currently, amebiasis is still a serious public health problem because parasitic infections are commonly neglected, particularly in populations that lack hygienic measures and clean drinking water $(1,3)$. In Mexico, amebiasis is one of the twenty major causes of disease; its incidence rate in 2000 was $1,353.43$ per $100,000(1,4,5)$.

Amebiasis is caused by the parasite Entamoeba histolytica, including both intestinal and extra-intestinal infections. This parasite can be present in sewage and contaminated water. According to its cell cycle, it can exist in two forms: trophozoites and cysts $(6,7)$. There is a second species with identical morphological characteristics to those described for E. histolytica called Entamoeba dispar; however, the biochemical, immunological and genetic data indicate that $E$. dispar is non-pathogenic (8). The life cycle in both species is the same. The infection begins with the ingestion of cysts from water or food contaminated with fecal matter. In the small intestine occurs the excystation and the trophozoites emerge. The trophozoites colonize the large intestine and adhere to the colonic mucosa $(6,9)$. Only the not encysted trophozoites of $E$. histolytica acquire invasiveness. By the action of proteases, hyaluronidases and mucopolysaccharidases $E$. histolytica erodes the mucosa producing ulcers and may even reach the submucosa. The adhesive interaction of the trophozoites with the surface of host cells is determinant for the invasion of human tissues, cytotoxic activity, and severity of the disease (10). Primary molecules involved in the intestinal invasion process of $E$. histolytica are the Gal/ Gal NAc lectin and EhCPADH112 (124 kDa) complex $(11,12)$. This complex is formed by the genes: i) Ehcp112, encoding a cysteine protease $(50 \mathrm{kDa})$, and ii) Ehadh112, 
encoding an adhesin (75 kDa). Some studies have analyzed the molecular role of EhCPADH112 in E. histolytica, but it has not been identified in E. dispar (13).

The laboratory diagnosis of amebiasis is usually based on microscopy, immunological methods and polymerase chain reaction (PCR). The occurrence of non-pathogenic species (particularly $E$. dispar) causes a confusing scenario for a correct diagnosis of intestinal amebiasis and $E$. histolytica is often inaccurately reported or diagnosed $(8,14-16)$. The denaturing gradient gel electrophoresis (DGGE) is a well-established tool for molecular microbiology; this method makes possible the electrophoretic separation of DNA fragments on the basis of differences in nucleotide composition rather than their size $(17,18)$.

To address the need for a reliable diagnostic test of amebiasis caused by $E$. histolytica in human stools, we developed a polymerase chain reaction-denaturing gradient gel electrophoresis (PCR-DGGE), which differentiates $E$. histolytica from $E$. dispar, as it is highly specific and sensitive to these two species (more specific than other techniques such as ELISA). The PCR primers were based on a conserved portion of the adh112 gene spanning a region with substitutions that allowed the differentiation between pathogen and non-pathogen species. To our knowledge, there are no studies using DGGE as a molecular identification technique to determine the prevalence of $E$. histolytica in Mexico.

\section{Material and Methods}

\section{Sample details}

The study involved 62 stool samples collected from patients who presented gastrointestinal complaints and attended the "Maximiliano Dorantes" Health Center. They were all examined for intestinal parasites using coproparasitoscopic studies (for multiple ova and parasites); we used the method of Faust with subsequent staining with Lugol solution in order to find cysts $(19,20)$. We used E. histolytica DNA as a positive control, which was obtained from a monogenic culture of strain HM-1 IMSS donated by the Molecular Diagnostic Laboratory, Department of Experimental Pathology CINVESTAV. Likewise, DNA of E. dispar was also used as a positive control; this was donated by the Department of Experimental Medicine, Faculty of Medicine UNAM. The coproparasitoscopic tests were performed in triplicate.

\section{DNA extraction}

The DNA of controls (E. histolytica and E. dispar) as well as the 62 studied samples were obtained directly from stools stored at $-20^{\circ} \mathrm{C}$, by means of Entamoeba cysts mechanical lysis, using zircon beads of $0.01 \mathrm{~mm}$ in diameter and then using the Wizard ${ }^{\mathbb{R}}$ Genomic DNA Purification Kit (Promega, USA) following the manufacturer's recommendations. As negative controls, we used human DNA extracted from whole blood of volunteer donors. We also utilized the
Wizard $^{(\mathbb{R}}$ Genomic DNA Purification Kit to isolate DNA from white blood cells. The DNA samples were stored at $-20^{\circ} \mathrm{C}$ until analyzed.

\section{Bioinformatic analysis for primer design}

In order to differentiate the orthologous adh112 gene of $E$. dispar from the adhesin of E. histolytica, a basic local alignment search tool (BLAST) was performed using the sequence reported by Garcia-Rivera et al. (21) obtained from GenBank database with accession number: AF127375 (E. histolytica). Taking this as a target sequence, it was aligned using the BLAST tool in the genome database of all organisms to find highly conserved regions. E. dispar showed $93 \%$ sequence identity with the adhesin gene from $E$. histolytica (accession No.: AANV02000421).

According to the high similarity between the two sequences, it was necessary to select a part of the sequence containing five differences for at least one nucleotide, because the DGGE is sensitive enough to detect differences of a single base between two sequences. The BioEdit (22) and GeneDoc (www.psc.edu/biomed/genedoc) softwares were used to interpret multiple alignments and manual adjustments. The alignment of $E$. histolytica and $E$. dispar sequences allowed the selection of a 228 bp-region containing five single base differences throughout the sequence (from base 916 to 1144) to be further amplified by PCR (Figure 1).

An in silico analysis to examine the complementarity within the sequence of each primer was performed using the Oligonalyzer program (www.idtdna.com/Home/Home.aspx). The designed primers also amplified another species of amoeba: E. nuttalli; however, its selected 228 bp-region did not contain the five single base differences observed in $E$. histolytica and E. dispar, so it was not included in our analysis. Moreover, E. nuttalli is non-pathogenic for humans and therefore, not important for our study (23). In order to achieve greater sensitivity in the detection by DGGE between $E$. histolytica and $E$. dispar, a GC-clamp was added to the forward primer: $5^{\prime}$-CGCCCGCCGCGCGGCCGCGG CCGGCCGGGGGCACGCGGCG-3' (24), changing the total size of the fragment to be amplified from 228 to $268 \mathrm{bp}$.

\section{PCR amplification of adh111 gene}

We tested various quantities of DNA (25, 50, and $100 \mathrm{ng})$ for PCR amplification and decided to use $100 \mathrm{ng}$ of DNA. For the first amplification, a reaction volume of $25 \mu \mathrm{L}$ comprised: $4 \mu \mathrm{L}$ of $10 x P C R$ buffer (Invitrogen, USA), $3.2 \mu \mathrm{L}$ of $\mathrm{MgCl}_{2}$ (50 mM; Invitrogen, USA), $1 \mu \mathrm{L}$ of dNTP's mix (10 mM each; Invitrogen), $0.3 \mu \mathrm{L}$ of each primer $(40 \mu \mathrm{M}), 0.2 \mu \mathrm{L}(5 \mathrm{U} / \mu \mathrm{L})$ of Accu Prime ${ }^{\mathrm{TM}}$ TaqDNA Polymerase High Fidelity (Invitrogen, USA), $2 \mu \mathrm{L}$ (100 ng) of DNA and $14 \mu \mathrm{L}$ of sterile deionized water. Finally, 2 drops of mineral oil were added. The amplification program of DNA started with 2 min of denaturation at $94^{\circ} \mathrm{C}$, followed by 40 cycles of $60 \mathrm{~s}$ at $92^{\circ} \mathrm{C}$ of denaturation, primer annealing for $60 \mathrm{~s}$ at $47^{\circ} \mathrm{C}$ and extension for $90 \mathrm{~s}$ at $72^{\circ} \mathrm{C}$. The final extension was at $72^{\circ} \mathrm{C}$ for $7 \mathrm{~min}$. We used the 


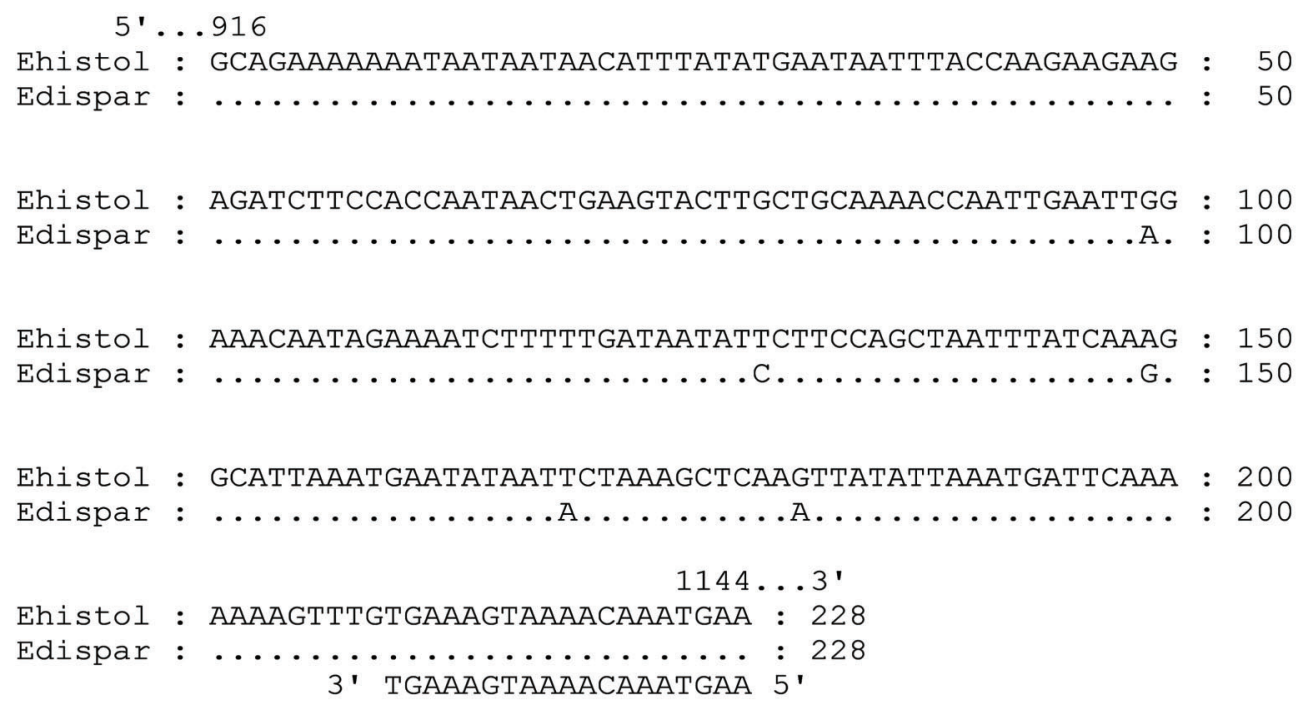

Figure 1. Alignment sequence between the adh112 gene fragments from $E$. histolytica and $E$. dispar. Five differences between sequences are highlighted.

primers: Fw 5'-GCA GAA AAA AAT AAT AAT AAC-3' and Rv 5'-TTC ATT TGT TTT ACT TTC A-3'. After the first PCR, $5 \mu \mathrm{L}$ of the amplified product were used for a second amplification under the same conditions mentioned above, using the primers: Fw 5'-CGC CCG CCG CGC GGC CGC GGC CGG CCG GGG GCA CGC GGC GGC AGA AAA AAA TAA TAA TAA C-3' and Rv 5'-TTC ATT TGT TTT ACT TTC A-3'. Both amplifications were done in triplicate. PCR amplification products were verified on $1.6 \%(\mathrm{w} / \mathrm{v})$ agarose gel using electrophoresis containing ethidium bromide.

\section{Denaturing gradient gel electrophoresis}

The PCR products were subjected to DGGE with 10 and $30 \%$ linear denaturing gradients of urea and formamide in a $10 \%$ polyacrylamide gel (Promega, USA). DGGE was performed with a $10-30 \%$ denaturing gradient adding $210 \mu \mathrm{L}$ of $10 \%$ ammonium persulfate and $10 \mu \mathrm{L}$ of tetramethylethylenediamine (TEMED). The electrophoresis was pre-run in 1XTAE buffer $(40 \mathrm{mM}$ Tris, $20 \mathrm{mM}$ acetic acid, $1 \mathrm{mM}$ EDTA, $\mathrm{pH}$ 8.0) at constant $200 \mathrm{~V}$ during $15 \mathrm{~min}$ and at $60^{\circ} \mathrm{C}$ using the Bio-Rad (USA) D-Code TM Universal Mutation Detection System. The final conditions for electrophoresis gels were $5 \mathrm{~h}$ and $30 \mathrm{~min}$ at $130 \mathrm{~V}$; the presence of PCR products was visualized by gel staining with $1 \mu \mathrm{g} / \mathrm{mL}$ of ethidium bromide for 2 min at room temperature and photographed by UV transillumination.

\section{Nested PCR-RFLP of SSU rRNA gene}

For the first amplification, a reaction volume of $25 \mu \mathrm{L}$ comprised: $2.5 \mu \mathrm{L}$ of $10 x$ PCR buffer (Invitrogen), $2 \mu \mathrm{L}$ of $\mathrm{MgCl}_{2}$ (50 mM; Invitrogen), $0.64 \mu \mathrm{L}$ of dNTP's mix (10 mM each; Invitrogen), $0.6 \mu \mathrm{L}$ of each primer $(40 \mu \mathrm{M}), 0.2 \mu \mathrm{L}$ (5 U/ $\mu \mathrm{L}$ ) of de Accu Prime ${ }^{\mathrm{TM}}$ TaqDNA Polymerase High
Fidelity (Invitrogen), $2 \mu \mathrm{L}$ (100 ng) of DNA, and $16.5 \mu \mathrm{L}$ of sterile deionized water. Finally, 2 drops of mineral oil were added. The DNA amplification program started with 2 min of denaturation at $94^{\circ} \mathrm{C}$, followed by 40 cycles of $60 \mathrm{~s}$ at $92^{\circ} \mathrm{C}$ of denaturation, primer annealing for $60 \mathrm{~s}$ at $47^{\circ} \mathrm{C}$ and extension for $90 \mathrm{~s}$ at $72^{\circ} \mathrm{C}$; the final extension was at $72^{\circ} \mathrm{C}$ for $7 \mathrm{~min}$. The primers used in this PCR were: Fw 5'-TTT GTA TTA GTA CAA A-3'; Rv 5'-GTA [A/G]TA TTG ATA TAC T- $3^{\prime}$. Later, we used $4 \mu \mathrm{L}$ of the first PCR product as a template for the nested PCR reaction with $4 \mu \mathrm{L}$ of 10x PCR buffer (Invitrogen), $3.2 \mu \mathrm{L}$ of $\mathrm{MgCl}_{2}$ (50 mM) (Invitrogen), $1 \mu \mathrm{L}$ of dNTP's mix (10 mM each) (Invitrogen), $1 \mu \mathrm{L}$ of each primer $(40 \mu \mathrm{M}), 0.2 \mu \mathrm{L}(5 \mathrm{U} / \mu \mathrm{L})$ of Accu Prime ${ }^{\mathrm{TM}}$ TaqDNA Polymerase High Fidelity (Invitrogen), 10.6 $\mu \mathrm{L}$ of sterile deionized water and 2 drops of mineral oil. The nested PCR was performed as described above using the first PCR conditions, except for the annealing temperature, which changed to $62^{\circ} \mathrm{C}$ and others primers were used: Selective for $E$. histolytica (Fw 5'-TTT AGA AAC AAT GCT TCT CT-3' and Rv 5'- AAT GGC CAA TTC ATT CAA TG-3') and selective for $E$. dispar (Fw 5'-AGT GGC CAA TTT ATG TAA GT-3' and Rv 5'-TTT AGA AAC AAT GTT TCT TC-3'). Both amplifications were done in triplicate. The amplified products were stained with ethidium bromide after electrophoresis on a $1.6 \%$ agarose gel. Positive and negative control reactions were included with each batch of samples analyzed by nested PCR. The nested PCR products of both E. histolytica and E. dispar showed approximately $874 \mathrm{bp}$ fragments which correspond to small ribosomal RNA subunit (SSU rRNA) gene. These products were digested with the restriction endonuclease Dral or Sau96I (5 U/ $\mu \mathrm{L}$; BIOLabs, New England) during $16 \mathrm{~h}$ at $37^{\circ} \mathrm{C}$ according to the manufacturer's 
instructions. The RFLP-digested product was visualized by loading $5 \mu \mathrm{L}$ of sample on a $1.6 \%$ agarose gel containing ethidium bromide.

\section{Results}

\section{Coproparasitoscopic exam of stool samples}

All samples were tested for E. histolytica and E. dispar using the Faust coproparasitoscopic exam. Of the 62 stool samples screened, 18 were positive for E. histolytica, 22 were positive for either Escherichia coli, E. nana, Giardia lamblia, or Ascaris lumbricoides cysts and negative for Entamoeba. Finally, 22 samples were negative for any parasite. No sample was positive for $E$. dispar.

\section{Specificity and sensitivity of PCR methods}

We found that the designed primers were specific for the expected fragment of $268 \mathrm{pb}$. This amplicon was observed in stool samples and positive controls ( $E$. histolytica and $E$. dispar). Figure 2 shows a visible amplicon of $268 \mathrm{pb}$ in the analyzed samples. Although other amplicons were detected in the stool samples and negative controls, it should be noted that they were not found in the positive controls.

\section{Clinical evaluation of PCR-DGGE-adh112 assay}

Once the DNA was isolated from stool samples, the primers were selected and concentrations standardized, the denaturant conditions were fully optimized, then DGGE gels were run (Figure 3). Out of the 62 samples, $10(16.1 \%)$ were positive for E. histolytica, while 52 (83.9\%) were negative. No sample was found to be positive for $E$. dispar.

\section{Nested PCR-RFLP of SSU rRNA gene}

The RFLP pattern for E. histolytica showed $563 \mathrm{bp}$ and $311 \mathrm{bp}$ fragments and an undigested $874 \mathrm{bp}$ fragment, whereas that for $E$. dispar showed $743 \mathrm{bp}$ and $131 \mathrm{bp}$ fragments (Figure 4). The nested PCR-RFLP was positive for $E$. histolytica in $10(16.1 \%)$ stool samples and 52 $(83.9 \%)$ samples were negative. These results are similar to what we observed with the PCR-DGGE technique, that is, the positive samples for $E$. histolytica by PCR-DGGE were also positive by PCR-RFLP. No sample was found to be positive for E. dispar. The sensitivity and specificity of both, PCR-DGGE and PCR-RFLP were 100\%. The 95\% $\mathrm{Cl}$ values were also estimated and used to evaluate the sensitivity $(95 \% \mathrm{Cl}=65.55-99.08)$ and specificity $(95 \%$ $\mathrm{Cl}=91.43-99.82)$ of PCR-DGGE technique.
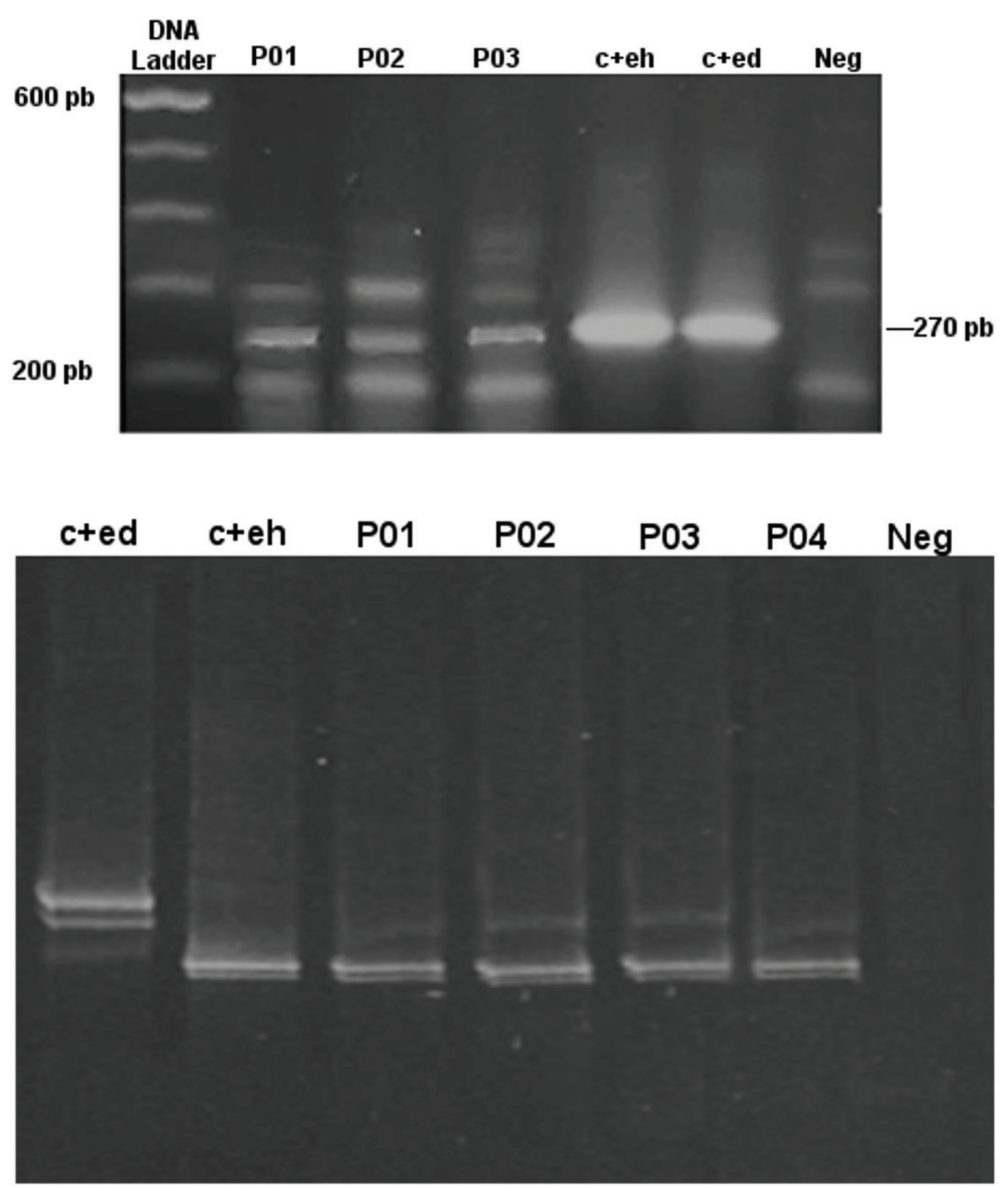

Figure 2. Stained agarose gel with products amplified by PCR with designed primers from samples containing $E$. histolytica or $E$. dispar. Lane 1, molecular weight marker; lanes 2-4, clinical samples; lane 5, DNA positive control for E. histolytica (c+eh); lane 6, DNA positive control for $E$. dispar (c+ed); and lane 7, negative control (human DNA from whole blood).

Figure 3. Denaturing gradient gel electrophoresis analysis of stool samples for the identification of $E$. histolytica and E. dispar. Lane 1, positive control of $E$. dispar; lane 2, positive control of $E$. histoIytica; lanes 3-6, clinical samples; lane 7, negative control. 


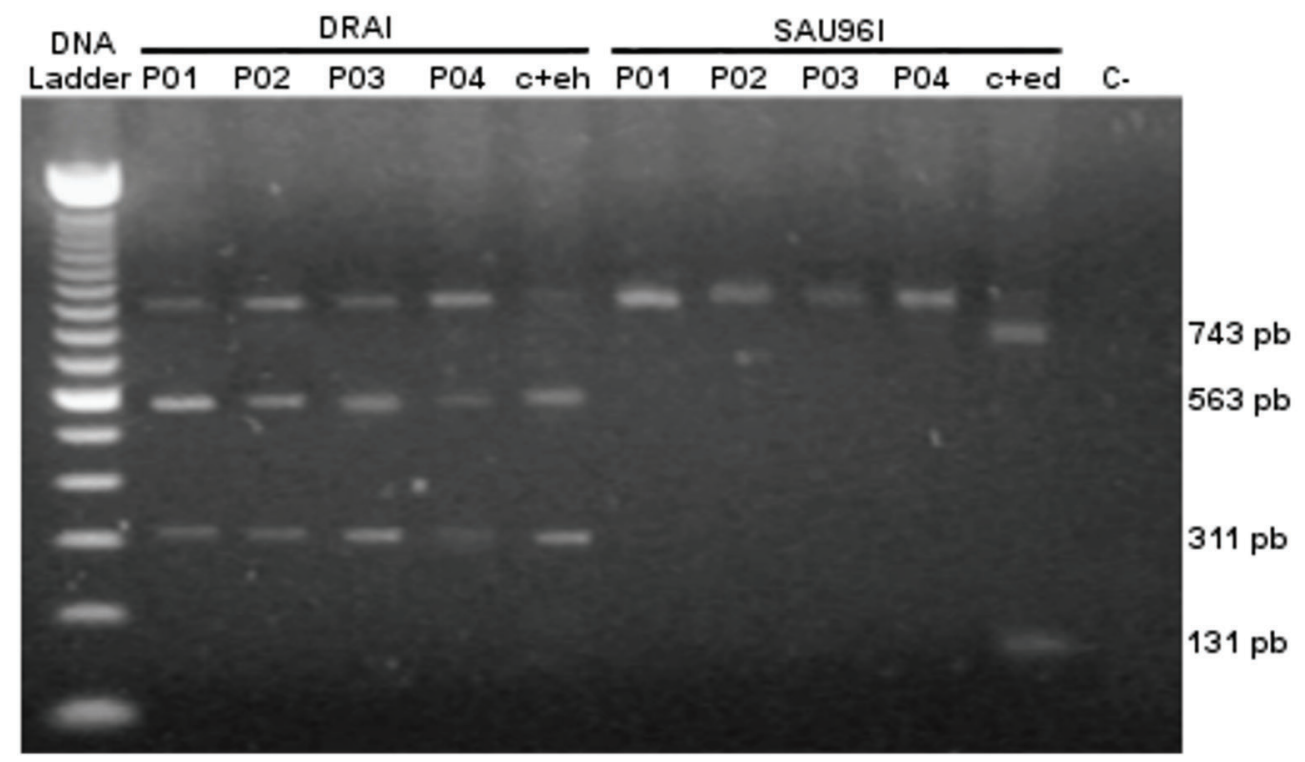

Figure 4. Nested PCR-RFLP (restriction fragment length polymorphism) of SSU rRNA gene for the identification of E. histolytica and E. dispar. Lane 1, molecular weight marker; lanes 2-5, Dral digested PCR products; lane 6, DNA positive control for E. histolytica (c+eh); lane 7-10, Sau96I digested PCR products; lane 11, DNA positive control for E. dispar (c+ed); and lane 12, negative control.

\section{Discussion}

The identification of Entamoeba spp. has always been controversial and microscopy is usually used to diagnose protozoa in stool samples. However, this method is unable to differentiate $E$. histolytica from the morphologically identical non-pathogenic species such as $E$. dispar $(8,14)$. Therefore, the WHO recommends the development and application of new methods for a specific diagnosis of E. histolytica infection (2). The present study describes a new PCR-DGGE strategy for species-specific detection and differentiation of $E$. histolytica and $E$. dispar DNA using stool samples. Several methods including isoenzyme analysis, antibody or antigen detection tests, immunochromatographic assays and real-time PCR have been used for an accurate detection of $E$. histolytica and E. dispar However, high cost limits their use in underdeveloped countries and, additionally, some yield false negative results (25-28).

Another alternative for differentiating the species is using PCR. This technique demonstrates exceptional sensitivity and specificity compared with microscopy $(8,14)$. This research is the first of its kind in Mexico, and was designed to detect and differentiate E. histolytica from E. dispar using a fragment of the adh112 gene, which presents five differences in single bases when comparing both species. The advantage of the PCR-DGGE-adh112 method over the PCR and restriction enzyme digestion method has to do with the reliability of the results. The electrophoretic pattern obtained in PCR and restriction enzyme digestion are based on the nucleotides size, and it can be difficult to see the differences and similarities that could exist among numerous samples (29). In contrast, DGGE is sensitive enough to detect differences of a single base. With the PCR-DGGE-adh112 the DNA fragments move through polyacrylamide gels containing a linear gradient of denaturing agents, resulting in a partially denatured molecule observed in the gel with distinctive electrophoretic pattern (the change in the sequence causes a change in the pattern of run), which gives greater effectiveness to the test and no likelihood of false positives or false negatives $(17,24)$.

In Mexico, there is a lack of knowledge about the epidemiology of $E$. histolytica infection, although amebiasis has been considered for many years as a major health problem in the country $(4,30)$. By using PCR-DGGEadh112 we found the mono infection with E. histolytica to be $16.1 \%$. No sample was found to be positive for E. dispar. These results were validated using another technique (nested PCR-RFLP of SSU rRNA gene) considered by several authors as the gold standard for the differential diagnosis between $E$. histolytica and E. dispar (31-34). Our results were consistent with those observed by PCR-RFLP. Our PCR-DGGE-adh112 results showed sensitivity and specificity of $100 \%$, indicating that it is a useful and reliable test to specifically detect E. histolytica in stool samples. PCR-DGGE has the advantage of identifying and differentiating $E$. histolytica and 
E. dispar, which is not possible using microscopy or ELISA $(8,35)$. It should be noted that the differentiation of pathogenic $E$. histolytica from the morphologically identical E. dispar is important for the clinical management of patients.

\section{References}

1. Ximénez $C$, Morán $P$, Rojas $L$, Valadez $A$, Gómez $A$. Reassessment of the epidemiology of amebiasis: state of the art. Infect Genet Evol 2009; 9: 1023-1032, doi: 10.1016/ j.meegid.2009.06.008.

2. Anonymous. Amoebiasis. Wkly Epidemiol Rec 1997; 72: 97-99.

3. Stauffer W, Abd-Alla M, Ravdin Jl. Prevalence and incidence of Entamoeba histolytica infection in South Africa and Egypt. Arch Med Res 2006; 37: 266-269, doi: 10.1016/j. arcmed.2005.10.006.

4. Caballero-Salcedo A, Viveros-Rogel M, Salvatierra B, TapiaConyer R, Sepulveda-Amor J, Gutierrez G, et al. Seroepidemiology of amebiasis in Mexico. Am J Trop Med Hyg 1994: 50: 412-419.

5. Ramos F, Morán P, González E, García G, Ramiro M, Gómez A, et al. High prevalence rate of Entamoeba histolytica asymptomatic infection in a rural Mexican community. Am J Trop Med Hyg 2005; 73: 87-91.

6. Begum S, Quach J, Chadee K. Immune evasion mechanisms of Entamoeba histolytica: progression to disease. Front Microbiol 2015; 6: 1394, doi: 10.3389/fmicb.2015.01394

7. Sepulveda B. Amebiasis: host-pathogen biology. Rev Infect Dis 1982; 4: 1247-1253, doi: 10.1093/clinids/4.6.1247.

8. Fotedar R, Stark D, Beebe N, Marriott D, Ellis J, Harkness J. Laboratory diagnostic techniques for Entamoeba species. Clin Microbiol Rev 2007; 20: 511-532, doi: 10.1128/ CMR.00004-07.

9. Luna-Nácar M, Navarrete-Perea J, Moguel B, Bobes RJ, Laclette JP, Carrero JC. Proteomic study of Entamoeba histolytica trophozoites, cysts, and cyst-like structures. PLoS One 2016; 11: e0156018, doi: 10.1371/journal.pone.0156018.

10. Aguirre Garcia M, Gutierrez-Kobeh L, Lopez Vancell R. Entamoeba histolytica: adhesins and lectins in the trophozoite surface. Molecules 2015; 20: 2802-2815, doi: 10.3390/ molecules20022802.

11. Ralston KS, Petri WA. The ways of a killer: how does Entamoeba histolytica elicit host cell death? Essays Biochem 2011; 51: 193-210, doi: 10.1042/bse0510193.

12. Ralston KS, Petri WA Jr. Tissue destruction and invasion by Entamoeba histolytica. Trends Parasitol 2011; 27: 254-263, doi: 10.1016/j.pt.2011.02.006.

13. Betanzos A, Javier-Reyna R, García-Rivera G, Bañuelos C, González-Mariscal L, Schnoor M, et al. The EhCPADH112 complex of Entamoeba histolytica interacts with tight junction proteins occludin and claudin-1 to produce epithelial damage. PLoS One 2013, 8: e65100, doi: 10.1371/journal. pone.0065100.

14. Tanyuksel M, Petri WA Jr. Laboratory diagnosis of amebiasis. Clin Microbiol Rev 2003: 16: 713-729, doi: 10.1128/ CMR.16.4.713-729.2003.

15. Ramos F, Morán P, González E, García G, Ramiro M, Gómez $\mathrm{A}$, et al. Entamoeba histolytica and Entamoeba dispar:
In conclusion, the present study reports a new PCR-DGGE technique for species-specific detection and differentiation of $E$. histolytica and $E$. dispar DNA in stool samples. This technique could become an alternative or a complementary diagnostic tool.

prevalence infection in a rural Mexican community. Exp Parasitol 2005; 110: 327-330, doi: 10.1016/j.exppara.2005. 03.015 .

16. Khairnar K, Parija SC, Palaniappan R. Diagnosis of intestinal amoebiasis by using nested polymerase chain reaction-restriction fragment length polymorphism assay. J Gastroenterol 2007; 42: 631-640, doi: 10.1007/s00535007-2080-6.

17. Ercolini D. PCR-DGGE fingerprinting: novel strategies for detection of microbes in food. $J$ Microbiol Methods 2004; 56 : 297-314, doi: 10.1016/j.mimet.2003.11.006.

18. Righetti PG, Gelfi C. Analysis of clinically relevant, diagnostic DNA by capillary zone and double-gradient gel slab electrophoresis. J Chromatogr A 1998; 806: 97-112, doi: 10.1016/S0021-9673(97)00304-X.

19. Chaves A, de Alcantara OS, Carvalho OS, dos Santos JS. [Comparative study of Lutz, Kato-Katz and modified Faust coprologic methods]. Rev Saúde Pública 1979; 13: 348-352.

20. Faust EC. Parasitologic surveys in Cali, Departamento del Valle, Colombia. I. Incidence and morphologic characteristics of strains of Entamoeba histolytica. Am J Trop Med Hyg 1958; 7: 4-15.

21. García-Rivera G, Rodríguez MA, Ocádiz R, Martínez-López MC, Arroyo R, González-Robles A, et al. Entamoeba histolytica : a novel cysteine protease and an adhesin form the $112 \mathrm{kDa}$ surface protein. Mol Microbiol 1999; 33: 556-568, doi: 10.1046/j.1365-2958.1999.01500.x.

22. Hall TA. BioEdit: a user-friendly biological sequence alignment editor andanalysis program for Windows 95/98/NT. Nucleic Acids Symp Ser 1999; 41: 95-98.

23. Tachibana $\mathrm{H}$, Yanagi $\mathrm{T}$, Feng $\mathrm{M}$, Bandara KB, Kobayashi $S$, Cheng $X$, et al. Isolation and molecular characterization of Entamoeba nuttalli strains showing novel isoenzyme patterns from wild toque macaques in Sri Lanka. J Eukaryot Microbiol 2016; 63: 171-180, doi: 10.1111/ jeu.12265.

24. Sheffield VC, Cox DR, Lerman LS, Myers RM. Attachment of a 40-base-pair $\mathrm{G}+$ C-rich sequence (GC-clamp) to genomic DNA fragments by the polymerase chain reaction results in improved detection of single-base changes. Proc Natl Acad Sci U S A 1989; 86: 232-236, doi: 10.1073/pnas. 86.1.232.

25. Calderaro A, Piergianni M, Buttrini M, Montecchini S, Piccolo G, Gorrini C, et al. MALDI-TOF mass spectrometry for the detection and differentiation of Entamoeba histolytica and Entamoeba dispar. PLoS One 2015; 10: e0122448, doi: 10.1371 /journal.pone.0122448.

26. Chavez-Munguia B, Martinez-Palomo A. High-resolution electron microscopical study of cyst walls of Entamoeba spp. J Eukaryot Microbiol 2011; 58: 480-486, doi: 10.1111/ j.1550-7408.2011.00576.x. 
27. Barnawi AB, Tonkal AM, Fouad MA, Al-Braiken FA. Detection of Entamoeba histolyticaldispar in stool specimens by using enzyme-linked immunosorbent assay in the population of Jeddah City, Saudi Arabia. J Egypt Soc Parasitol 2007;37: 143-150.

28. Spadafora LJ, Kearney MR, Siddique A, Ali IK, Gilchrist $\mathrm{CA}$, Arju T, et al. Species-specific immunodetection of an Entamoeba histolytica cyst wall protein. PLoS Negl Trop Dis 2016; 10: e0004697, doi: 10.1371/journal.pntd.0004697.

29. Noor Azian MY, Lokman Hakim S, Maslawaty MN. Use of molecular tools to distinguish Entamoeba histolytica and Entamoeba dispar infection among the aborigines in Cameron Highlands. Trop Biomed 2006; 23: 31-36.

30. González CR, Isibasi A, Ortiz-Navarrete V, Paniagua J, García JA, Ramirez A, et al. Prevalence of antibodies against Entamoeba histolytica in Mexico measured by ELISA. Epidemiol Infect 1995;. 115: 535-543, doi: 10.1017/S0950 268800058702.

31. Troll $\mathrm{H}$, Marti $\mathrm{H}$, Weiss $\mathrm{N}$. Simple differential detection of Entamoeba histolytica and Entamoeba dispar in fresh stool specimens by sodium acetate-acetic acid-formalin concentration and PCR. J Clin Microbiol 1997; 35: 1701-1705

32. Haque R, Ali IK, Akther S, Petri WA Jr. Comparison of PCR, isoenzyme analysis, and antigen detection for diagnosis of Entamoeba histolytica infection. J Clin Microbiol 1998; 36: 449-452.

33. Katzwinkel-Wladarsch S, Loscher T, Rinder H. Direct amplification and differentiation of pathogenic and nonpathogenic Entamoeba histolytica DNA from stool specimens. Am J Trop Med Hyg 1994; 51: 115-118.

34. Clark CG, Diamond LS. Ribosomal RNA genes of 'pathogenic' and 'nonpathogenic' Entamoeba histolytica are distinct. Mol Biochem Parasitol 1991; 49: 297-302, doi: 10.1016/0166-6851(91)90073-F.

35. Zeyrek FY, Turgay N, Unver A, Ustün S, Akarca U, Töz S. Differentiation of Entamoeba histolyticalEntamoeba dispar by the polymerase chain reaction in stool samples of patients with gastrointestinal symptoms in the Sanliurfa Province. Turkiye Parazitol Derg 2013; 37: 174-178, doi: 10.5152/ tpd.2013.39. 